\title{
PELATIHAN DAN PENGEMBANGAN KETERAMPILAN MENGAJAR GURU PENDIDIKAN ANAK USIA DINI
}

\author{
Ida Bagus Alit Arta Wiguna') \\ 1)Pendidikan Guru Pendidikan Anak Usia Dini, Dharma Acarya, Institut Agama Hindu Negeri Gde Pudja Mataram, \\ Mataram, Nusa Tenggara Barat, Indonesia \\ Corresponding author : Ida Bagus Alit Arta Wiguna \\ E-mail : gusarta.iahn@gmail.com
}

Diterima 02 April 2021, Direvisi 08 April 2021, Disetujui 09 April 2021

\begin{abstract}
ABSTRAK
Guru pendidikan anak usia dini merupakan garda terdepan dalam pengembangan karakter dan kemampuan anak diusia keemasannya. Sehingga memerlukan guru pendidikan anak usia dini yang berkompeten terutama dibidang proses belajar mengajar. Pengabdian ini memiliki tujuan yakni menambah pemahaman guru terkait pentingnya keterampilan mengajar dan pentingnya studi dijurusan yang linier. Metode pengabdian ini terdiri dari metode ceramah, diskusi, demontrasi dan metode pratik langsung. Pentingnya hasil dari pengabdian ini adalah untuk meningkatkan keterampilan guru PAUD terutama saat perencanaan dan proses belajar mengajar berlangsung. Pentingnya kuliah yang linier untuk meningkatkan kompetensi guru PAUD. Peningkatan pemahaman dan kemampuan guru paud sangat signifikan berdasarkan dari hasil pre test dan post test yang telah disebar mengalami peningkatan di setiap katagori, seperti katagori kegiatan mengalami peningkatan $24 \%$, katagori Kegiatan inti $23 \%$ dan katagori penutup $27 \%$. Serta dapat dilihat juga dengan pertanyaan dan jawaban yang disampaikan oleh guru.
\end{abstract}

Kata kunci: keterampilan; kompetensi; pembelajaran mikro; PAUD

\begin{abstract}
Kindergarten teachers are at the forefront of developing the character and abilities of children at their golden age. So that it requires competent early childhood education teachers, especially in the field of teaching and learning processes. This service has the aim of increasing the teacher's understanding of the importance of teaching skills and the importance of linear studies. This service method consists of lectures, discussions, demonstrations and hands-on practical methods. The importance of the results of this service is to improve the skills of kindergarten teachers, especially during the planning and teaching and learning process. The importance of linear lectures to improve the competence of early childhood teachers. The increase in the understanding and ability of paud teachers is very significant based on the results of the pre-test and post-test that have been distributed, which has increased in each category, such as the activity category increased by $24 \%$, the core activity category was $23 \%$ and the closing category was $27 \%$. And it can be seen also by the questions and answers submitted by the teacher.
\end{abstract}

Keywords: skills; competencies; microteahing; kindergarten

\section{PENDAHULUAN}

Pendidikan

ialah

proses

mengembangkan potensi manusia sepanjang hayat (Ardika Yasa, 2020). Salah satu ada di fase pendidikan usia dini. UU SISDIKNAS No 20 Tahun 2003 bagian ketujuh menerangkan bahwa upaya pembinaan kepada anak itu dari sejak lahir sampai usia enam tahununtuk membantu pertumbuhan dan perkembangan jasmani dan rohani agar anak memiliki kesiapan dalam memasuki pendidikan lebih lanjut (Rudiarta, 2020) dan UU No 23 Tahun 2002 menjelaskna tentang Perlindungan anak pada pasal 9 ayat 1 menerangkan bahwa anak berhak memperoleh pendidikan dan pengajaran dalam rangka pengembangan pribadi dan tingkat kecerdasan yang sesuai dengan minat dan bakat. Konsep ini dijabarkan dalam kebijakan pemerintah di bidang kurikulum pendidikan anak usia dini. Kebijakan pendidikan nasional dikembangkan dalam kurikulum 2013 (Kemendikbud, 2013).

Disisilain kebijakan pemerintah dan para ahli juga mengupayakan pengembangan bentuk-bentuk kecerdasan dan indikatornya untuk Taman Kanak-kanak (Gunada \& Yoga Pramana, 2021). Dalam mengembangkan bentuk-bentuk kecerdasan dalam pelaksanaan pembelajaran diperlukan keterampilan dan pengetahuan memumpuni yang harus dimiliki oleh guru agar tujuan pemebelajaran tercapai dengan dengan optimal sesuai dengan 
kemampuan dan potensi peserta didik (Kasiyan et al., 2019). Proses pendidikan di sekolah menjadi tugas guru sedangkan pendidikan dirumah menjadi tanggung jawab orang tua. Dalam mencerdaskan peserta didik guru dituntut harus menguasai tehnik dalam pembelajaran atau lebih dikenal dengan istilah teaching.

Untuk melatih proses pemberian pembelajaran atau mengajar memerlukan cara yang terstruktur dan juga harus menempuh jenjang perkuliahan jurusan pendidikan. Karena dalam jurusan pendidikan diberikan mata kuliah pemebelajaran mikro atau yang lebih sering didengar adalah mikroteaching. Dimana dalam perngertiannya microteaching ialah MC Knight dalam Asmani (2011) Microteaching has been described as scaled down teaching encounter designed to develop new skills and refine old ones. Dapat digambarkan sebagai prosespengajaran yang diperkecil, yang didesain untuk mengembangkan ketrampilan baru dan mengembangkan keterampilan yang telah dimiliki dan sebagai tehnik pelatihan calon guru dan guru untuk menambah keterampilannya. Pembelajaran mikro yang dimaksud disini adalah cara guru menyampaikan materi atau tema pada pembelajaraan saat proses pembelajaran berlangsung (Kasiyan et al., 2019).

$$
\text { Mengingat pentingnya terkait }
$$

kemampuan guru maka bisa dikatakan guru ialah garda terdepan dalam bidang pendidikan sehingga harus didukung oleh pemerintah, warga masyarakat dan kemampuan guru sendiri seperti pengetahuan, keterampilan, maupun sikap yang ditampilkan dalam prilaku cerdas dan penuh tanggung jawab yang dimiliki guru dalam menjalankan profesinya.

Sesuai dengan bunyi Peraturan Pemerintah pasal 28 no 19 Tahun 2005, tentang Standar Nasional Pendidikan, pada ayat 1 menyebutkan bahwa pendidik harus mempunyai kualifikasi akademik dan kompetensi sebagai agen pembelajaran, sehat jasmani dan rohani, serta kemampuan untuk mewujudkan tujuan pendidikan nasional. Sedangkan pada ayat 3 disebutkan kompetensi yang perlu dikuasai oleh seorang guru yakni : kompetensi pedagogik, kompetensi pribadi, kompetensi sosial dan kompetensi profesional. Penguasaan kompetensi ini harus dipelajari secara bertahap sehingga menjadi guru yang profesional dan memumpuni dibidang ilmu yang dikuasai. Berhubungan dengan sikap profesionalisme sesuai dengan Undang Undang No 14 Tahun 2005 tentang Guru dan Dosen, tercantum sebagai pekerjaan atau kegiatan yang dilakukan oleh seseorang menjadi sumber penghasilan kehidupan yang memerlukan keahlian, kemahiran atau kecakapan yang memenuhi standar mutu. Amanah UU yang dimaksud, untuk menegaskan bahwa betapa pada hakikatnya, secara impretatif setiap pendidik dituntut untuk selalu belajar bagaimana menjadi guru yang profesional dan memiliki kompetensi yang memumpuni (kemensetneg, 2005).

Empat kompetensi yang harus dimiliki oleh guru yakni pertama kompetensi pedagogik sangat penting dimiliki oleh guru PAUD. Pasalnya dengan kompetensi pedagogik guru pendidikan anak usia dini akan bisa membaca dan mengembangkan potensi, bakat, kecerdasan, dan gaya belajar anak usia dini. Kompetensi pedagogik guru PAUD sendiri tidak hanya berhubungan dengan kemampuan guru PAUD dalam merencanakan, melaksanakan, dan melakukan evaluasi terhadap proses pembelajaran (Yuliariatiningsih \& Setiaty, 2018). Kedua kompetensi pribadi ini sangatlah penting bagi guru PAUD. Meskipun guru PAUD memiliki kompetensi pedagogik yang sangat unggul akan tetapi apabila guru PAUD tidak memiliki kompetensi keperibdian jelas tidak akan bisa menjadi guru yang mampu membaca dan memaksimalkan semua potensi, bakat, kecerdasan, dan gaya belajar anak usia dini. Kompetensi pribadi merupakan pondasi awal sebagai guru sehingga mampu memberikan cohtoh kepada orang lain ( Felayati \& Nurhafizah, 2019). Ketigakompetensi sosial, kompetensi ini sama pentingnya dengan kompetensi yang lainnya, dengan memiliki kompetensi sosial yang baik maka guru akan mendapatkan relasi yang banyak terutama tentang pendidikan sehinnga ada tman diskusi (Murdri, 2010). Keempat keterampilan profesional,Guru PAUD wajib menjadi guru profesional karena sangat penting dan fundamental dalam mencerdaskan anak usia dini , serta dalam memaksimalkan bakat, potensi, kecerdasan dan gaya belajarnya. Kompetensi ini menjadi kekuatan guru sebagai pribadi profesionalnya (Sutarmanto, 2012).

Namun berdasarkan hasil pengamatan dan informasi yang diberikan oleh masyarakat yang perlu dilaksanakan saat pengabdian lintas nusantara di desa tampak siring, kecamatan timoni timur, kabupaten luwu timur provinsi Sulawesi Selatan. Terdapat satu sekolah Pendidikan Anak usia Dini (PAUD) berbasis keagamaan Hindu bernama TK Widya Sari yang kondisinya sangat memprihatinkan dari segi tenaga pendidik dan tenaga kependidikan. Terutama Guru - guru sebagai garda terdepan untuk bidang pendidikan namun guru yang ada bukan dari tamatan sarjana Pendidikan Guru Pendidikan anak Usia Dini atau tamatan dari sarjana pendidikan sehingga dalam 
mentransfer ilmu secara teori belum dipahami oleh para guru - guru yang ada.

$$
\text { Sehingga pelatihan dan }
$$

pengembangan keterampilan mengajar guru pendidikan anak usia dini sangat dibutuhkan dalam pengabdian lintas nusantara yang dilaksanakan oleh Perguruan Tinggi Sekolah Tinggi Agama Hindu Negeri Gde Pudja Mataram yang kini telah beralih status dari 16 Desember 2020 menjadi Institut Agama Hindu Negeri Gde Pudja Mataram. Pengabdian lintas nusantara mengambil tema "Mengintegrasikan Pendidikan, Seni dan Budaya Keagamaan Hindu dalam masyarakat kreatif dan inovatif berbasis kearifan lokal" yang dilaksanakan dari 27 November 2019 - 1 Desember 2019 dikarenakan waktu yang terbatas namun banyak permasalahan yang terjadi di lapangan maka tim dari pengabdian masyarakat luwu timur membagi anggota sesuai dengan bidang keilmuannya.

Setelah mendapatkan informasi, langkah pertama tim melaksanakan observasi langsung ke Sekolah TK Widya Sari. Tim pendidikan terdiri dari dua orang satu melatih tenaga pendidik (guru) dan satunya melatih tenaga kependidikan (Pegawai tata usaha). agar pengabdian kepada masyarakat bermanfaat maka dalam pelatihan tenaga pendidik langsung praktek dalam proses melaksanakan pembelajaran dikelas dengan mencontohkan best practice. Dari memberikan pemahaman keterampilan dasar mengajar, membuka dan menutup pelajaran, menjelaskan, mengadakan variasi, penguatan materi, bertanya, mengelola kelas, membagi kelompok dan membimbing kelompok.

Tujuan dari pengabdian masyarakat yang dilaksanakan selama lima hari yakni guru di TK Serathi Dharma mampu enambah pemahaman dan mampu melaksanakan proses belajar mengajar dengan baik sesuai dengan yang diamanatkan oleh Undang-undang serta menyarankan guru untuk menempuh pendidikan yang linier dengan keguruan.

\section{METODE}

Memahami permasalahan pada TK Serathi Dharma Dusun Tampak Siring, Kecamatan Timoho timur, Kabupaten Luwu Timur Provinsi Sulawesi Selatan Karena minimnya keterampilan guru saat melaksanakan proses perencanaan dan proses pembelajaran. Sedangkan tuntutan kualitas sebagai guru semakin tinggi. Realitas ini mengharuskan guru untuk menambah kompetensi dan keterampilannya agar mampu merealisasikan pendidikan sesuai yang diamanatkan oleh undang-undang. Salah satunya dengan melaksanakan proses pembelajaran dikelas sesuai dengan teori dan prakteknya agar tercapainya standar pendidikan nasional (Nurhafizah, 2018).

Untuk memecahkan permasalahan yang dicantumkan diatas, dan atas permintaan masyarakat melaksankan pelatihan dan mengembangkan keterampilan mengajar guru pendidikan anak usia dini. Adapun metode pelaksanaan pelatihan dan pengembangan, yakni :

1. Kegiatan hari Pertama bertemu dengan tokoh desa dan pemuka adat untuk mendapatkan arahan dan hal yang mendesak yang perlu ditangani sesuai bidang dan kemampuan kami.

2. Kegiatan Hari kedua setelah mendapatkan informasi dari masyarakat dilanjutkan dengan melaksankan Observasi kelapangan dan meberikan angket pre-test kepada guru di TK Serathi Dharma.

3. Kegiatan hari ketiga penyuluhan dalam rangka berbagi wawasan untuk guru dan kepala sekolah, terkait pentingnya linier pendidikan pada pendidikan guru pendidikan anak usia dini dan pembuatan $\mathrm{RPPH}$.

4. Kegiatan hari ke empat yakni praktik mengajar dikelas bersama peserta didik dan dilihat langsung oleh guru PAUD di TK. Serathi Dharma. Saat praktik mendapatkan tema binatang.

5. Kegiatan hari kelima yakni peberian angket post-test kepada guru sekaligus perpisahan dikarenakan akan balik pada malam harinya ke Provinsi Nusa Tenggara Barat.

Selama proses pembelajaran berlangsung, guru - guru yang berjumlah tiga orang, dua guru kelas dan satu kepala sekolah PAUD dibimbing secara individu oleh tim pengabdian. Dalam pelaksanaan kegiatan pengabdian kepada masyarakat ini menggunakan beberapa metode, yaitu :

1. Untuk penyampaian teori dan informasi menggunakan metode ceramah, dimana tim menyajikan materi dan setelah itu dilanjutkan dengan diskusi.

2. Untuk mengetahui penguasaan materi dan implementasi dari RPPH yang sudah dibuat menggunakan metode demontrasi atau peragaan dengan konsep pembelajaran mikro.

3. Metode praktek langsung dengan melaksanaan pembelajaran diawali dengan pembukaan, penyampaian proses pembelajaran dan penutup. Seperti penjabaran berikut. 
Proses kegiatan berlangsung seperti gambar diagram alir berikut :

\begin{tabular}{|c|}
\hline $\begin{array}{l}\text { A. Perencanaan } \\
\text { Mempersiapkan media pembelajaran, } \\
\text { Mempersiapkan RPPH }\end{array}$ \\
\hline $\begin{array}{l}\text { B. Proses Kegiatan } \\
\text { 1. Pembukaan, 2. Inti, 3. Recaling } \\
\text { 4. Penutup, 5. penilaian }\end{array}$ \\
\hline $\begin{array}{l}\text { 1. Pembukaan } \\
\text { SOP Pembukaan, diskusi binatang } \\
\text { amphibi, ciri-ciri binatang amphibi, } \\
\text { melompat seperti katak,menyampaikan } \\
\text { aturan bermain. ( } 20 \text { menit) }\end{array}$ \\
\hline $\begin{array}{l}\text { 2. Inti } \\
\text { Mengurutkan metamorfosis katak, } \\
\text { Mewarnai gambar katak, } \\
\text { mempraktekan suara katak, melompat } \\
\text { - lompat dikelas seperti katak, diskusi } \\
\text { dan tanya jawab (45 menit) }\end{array}$ \\
\hline $\begin{array}{l}\text { 3. Recaling } \\
\text { Merapikan media pembelajaran, } \\
\text { Diskusi tentang perasaan diri selama } \\
\text { melakukan kegiatan bermain, } \\
\text { menunjukkan hasil karyanya (15 menit) }\end{array}$ \\
\hline $\begin{array}{l}\text { 4. Penutup } \\
\text { Menginformasikan kegiatan untuk } \\
\text { besok, Penerapan SOP penutupan. ( } 5 \\
\text { menit) }\end{array}$ \\
\hline $\begin{array}{l}\text { 5. Penilaian } \\
\text { Sikap, Pengetahuan dan Keterampilan } \\
\text { ( } 5 \text { menit) }\end{array}$ \\
\hline
\end{tabular}

Gambar 1. Proses Pelaksanaan Pratik pembelajaran

4. Tahap akhir yaitu metode evaluasi dan analisis feedback, pembuatan laporan, evaluasi kegiatan untuk melihat ketercapaian tujuan dan pembuatan luaran berupa artikel untuk dipublikasikan di jurnal pengabdian masyarakat (Lestari \& Millenia, 2020).

HASIL DAN PEMBAHASAN
Kegiatan pengabdian kepada
masyarakat di Dusun Tampak Siring,

Kecamatan Timoho timur, Kabupaten Sulawesi Selatan pelaksanaan kegiatan diawali dengan sambutan dari pihak desa dan kecamatan. Kegiatannya seperti berikut

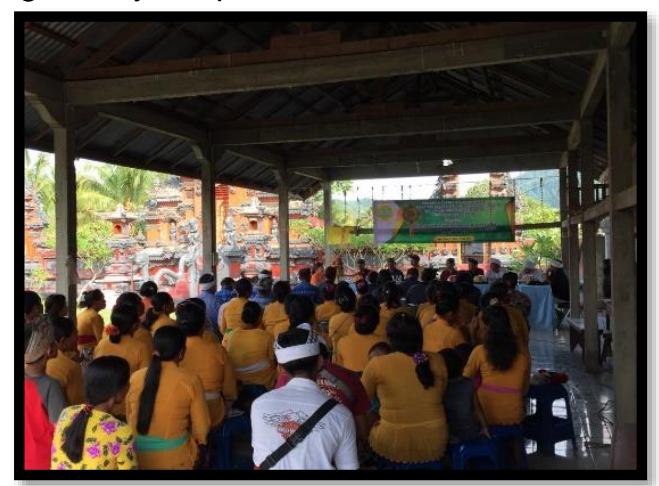

Gambar 2. Pembukaan PKM

Kegiatan ini berjalan dengan kondusif dan sekaligus menyesuaikan dengan program kerja yang sudah dipersiapkan dari hasil rapat tim yang diadakan di kampus.

Dengan berdiskusi dengan warga dan tokoh adat maka memperoleh beberapa program yang diinginkan oleh masyarakat untuk di terapkan. 1). Pelatihan tarian Bali. 2). Memainkan alat musik gambelan, 3). Tata rias busana ke Pura yang benar. 4). Pelatihan Yoga 5). Pelatihan tehnik mengajar AUD karena baru merintis sekolah PAUD. 6). Pelatihan pembuatan bahan upacara adat 7). Pementasa drama modern. Dari ketujuh program yang dipilih oleh warga maka tim yang ber homebase di program studi pendidikan guru pendidikan anak usia dini mendapatkan program nomor lima yaitu pelatihan dan pengembangan keterampilan mengajar guru pendidikan anak usia dini.

Setelah mengetahui program yang telah disepakati masyarakat maka tim pengabdian kepada masyarakat di bidang pendidikan pada hari pertama membuat perencanaan observasi ke TK. Serathi Dharma dan mempersiapkan apa saja yang perlu disediakan sebelum terjun kelapangan. Pada hari kedua tim pengabdian kepada masyarakat terjun ke TK. Serathi Dharma mengadakan observasi awal dan mewawancarai Kepala sekolah dan guru terkait dengan kendala dan masalah yang dihadapi selama melangsungkan proses belajar mengajar dikelas.

Kepala sekolah : kami disini TK. Serathi Dharma baru mengawali kurang lebih sudah berjalan selama tiga tahun, kami berlatih mengajar melalui youtube. Dan gugus disini namun belum pernah mempraktekan sesuai dengan isi rencana pelaksanaan pembelajaran harian atau singkatannya RPPH hanya sebagai bahan pelengkap administrasi. 
Dengan adanya hasil wawancara di atas maka menjadi pertimbangan tim dalam melaksanakan pelatihan dan pengembangan keterampilan mengajar guru pendidikan anak usia dini sesuai dengan arahan dan pakem dari pemerintah.

Selanjutnya mewawancarai guru terkait kendala dan masalah yang sering dihadapi saat proses belajar mengajar berlangsung. Guru menyatakan :

Anak-anak sering main ketika kita mulai menjelaskan materi sesuai tema. Ada yang usil dengan temannya. Pokoknya beragam sekali tingkah laku anak anak saat pembelajaran dalam kelas, kadang kami merasa kurang pengertian kadang kami menganggap itu cara anak menarik perhatian kita sebagai guru, kadang pula mereka tiba tiba menangis karena tidak ada yang memerhatikan.

Dari pernyataan guru di atas maka memang sangat diperlukan kemampuan dasar dalam melaksanakan pembelajaran sesuai dengan RPPH yang disusun oleh guru (Abril, 2016). Pada hari ketiga tim pengabdian mengadakan penyuluhan kepada guru dan terkait cara penyusunan RPPH sesuai pengembangan dengan kemampuan guru dan sesuai Permendikbud No 22 Tahun 2016 dan SE Mendikbud Nomor 14 Tahun 2019 (Mayudana \& Sukendra, 2020).Setelah guru mendapatkan pemahaman tentang penyusunan RPPH maka langsung kami mengarahkan kepada guru-guru untuk praktek pembuatan RPPH dengan kemampuan sendiri tanpa copy -paste punya orang sehingga kita selalu lupa menerapkan langkah langkahnya setiap proses pembelajaran dikelas.

Pada hari keempat tim pengabdian kepada masyarakat menyarankan guru memperoleh pengalaman mempraktekan pembelajaran sesuai dengan yang tersusun dalam RPPH namun guru meminta kepada tim untuk mempraktekan secara langsung kegiatan proses belajar mengajar di kelas yang sesuai dengan kita buat di hari sebelum.

Berdasarkan permintaan tersebut tim langsung mempraktekan dan membagikan pengalamannya kepada peserta didik langsung dan guru menyimak setiap langkah yang dipaparkan.

Langkah pertama yakni pembukaan pembelajaran dengan mengucapkan salam secara agama Hindu "OM Swastyastu" dilanjutkan berdiskusi dengan peserta didik terkait dengan binatang yang amphibi bisa hidup didarat maupun di air. Setelah anak mengetahui binatang katak. Guru mempraktekan suara katak kepada semua peserta didik secara berurutan dan saling bersahutan, dilanjutkan guru memberikan permainan melompat di lantai seperti cara berjalannya katak. Seperti yang terlihat dalam foto berikut :

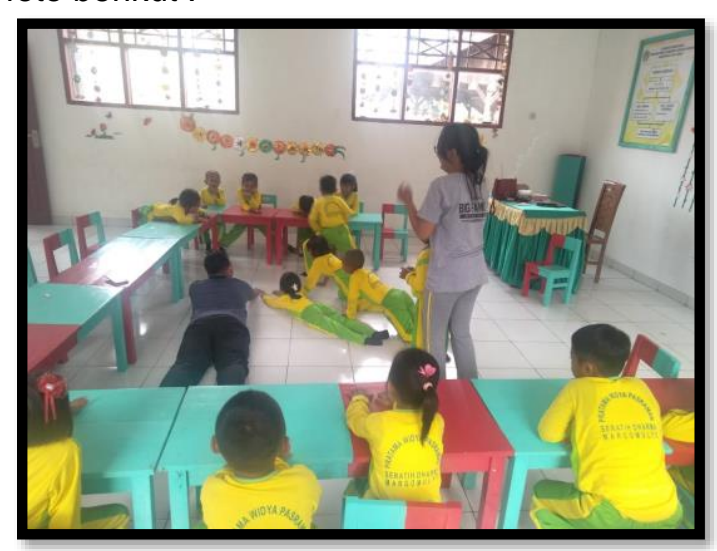

Gambar 3. Anak meniru cara belajar katak.

Memeragakan gaya berjalan katak diatas membantu menumbuhkembangkan fisik dan motorik anak usia dini sekaligus mengarahkan permainan yang menyenangkan dalam proses pelaksanaan pembelajaran.

Langkah kedua yakni pembelajaran Inti dengan memberitahukan metamorfosis katak memiliki empat proses dari telur - berudu berudu berkaki - sehingga menjadi katak dengan menunjukan media gambar seperti berikut.

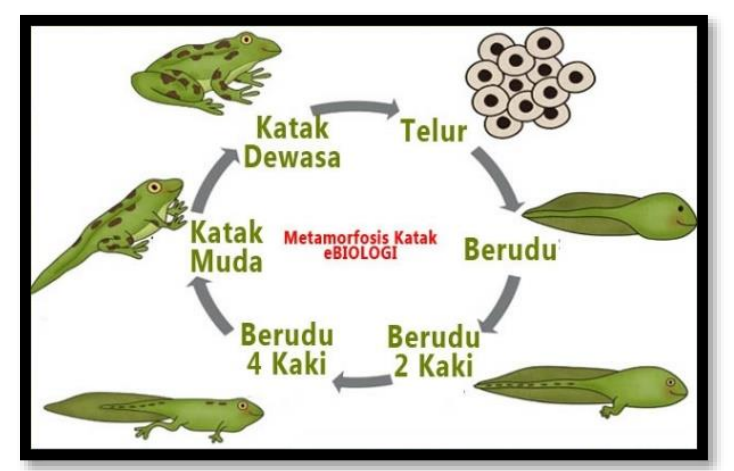

Gambar 4. Metamorfosis katak (Putra et al., 2012)

Dilanjutkan dengan mewarnai gambar yang sudah disiapkan sebagai stimulus motorik halus peserta didik. Terntunya kesesuaian warna yang di pakai dan kerapiannya yang dinilai oleh guru berdasarkan hasil yang dibuat anak usia dini. Setelah mewarnai anak diajak berkumpul untuk berdiskusi dan berani menjawab dan menanyakan pertanyaan kepada tim pengabdian. Seperti foto berikut : 


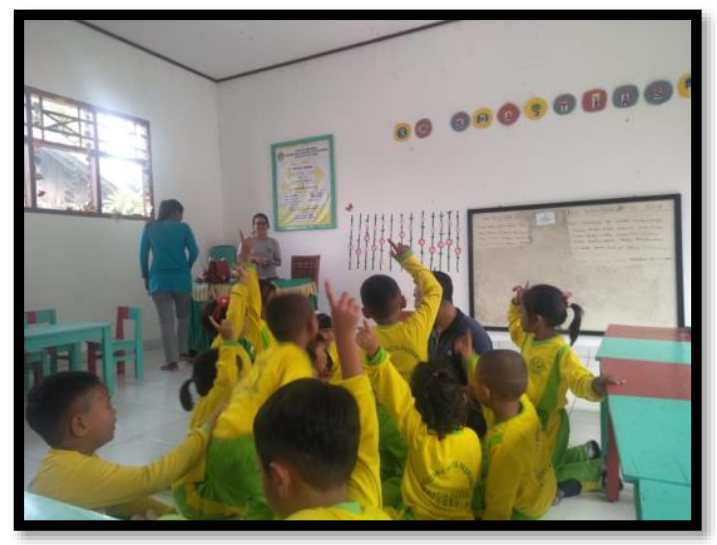

Gambar 5. Antusiasme belajar anak

Anak sangat antusias saat menjawab pertanyaan dan bertanya kepada tim pengabdian. Hampir seluruh siswa terlihat aktif dalam proses pelaksanaan pemebelajaran dikelas. Dilanjutkan dengan kegiatan ke tiga yakni recalling, tim menegaskan bahwa katak memiliki 4 metamorfosis dan mengatakan katak adalah hewan amphibi yang bisa hidup di air maupun di darat. Dan menanyakan kepada peserta didik apakah dala keadaan gembira mengikuti pemebelajaran berlangsung dikelas dengan serentak anak menjawabnya bahwa mereka sangat senang saat menerima pembelajaran dikelas. Kegiatan keempat yakni penutup dengan memberitahukan kegiatan besok dilanjutkan dengan berdoa penutup dan mengucapkan salam parama santi "Om Santih, Santih, Santih, Om". Setelah peserta didik pulang, guru memeriksa hasil dari mewarnai peserta didik dan emberikan penilaiannya.

Terjadi perubahan yang signifikan dari hasil pemberian angket saat observasi dan setelah pemberian pelatihan keterampilan mengajar guru. Seperti gambar diagram berikut.

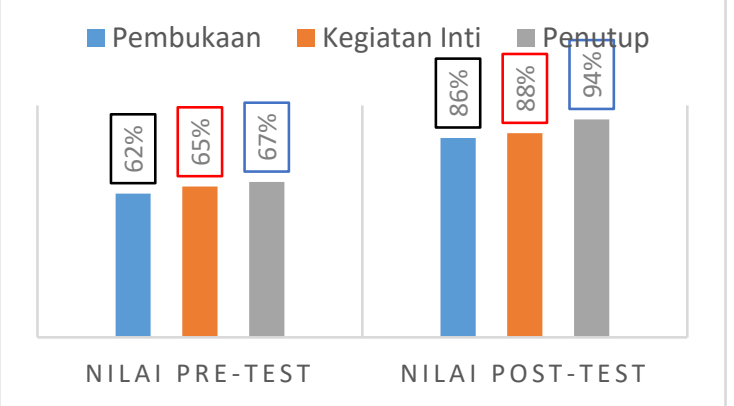

Gambar 6. Nilai Pre test \& Post test

Berdasarkan data diagram diatas menilai tiga sub komponen saat proses belajar mengajar berlangsung. Terjadinya peningkatan pemahaman di ketiga aspek penilaian, yang pertama pada aspek guru membuka pembelajaran mengalami peningkatan $24 \%$, kedua peningkatan pada kegiatan inti sejumlah
$23 \%$ serta yang ketiga peningkatan pemahaman di bagian penutup $27 \%$. Dengan demikian bahwa kegiatan pengabdian kepada masyarakat ini berhasil karena terjadi peningkatan yang signifikan dalam pemahaman dan praktek mengajar guru.

Dengan diadakanya pelatihan ini guru sangat terbantu dalam proses pelaksanaan pembelajaran baik dari perencanaan dalam pembuatan RPPH maupun mendapatkan pengalaman melihat secara langsung praktek pembelajaran yang sesuai diharapkan oleh pemerintah. Sehingga menambah wawasan guru untuk terus belajar perkembagan ilmu pengetahuannya. Dan sebagai hasil akhir tim pengabdian menganjurkan kepada guru di TK. Serathi Dharma untuk melanjutkan studinya mengambil jurusan yang sesuai dengan pekerjaannya yakni di prodi pendidikan guru pendidikan anak usia dini.

\section{SIMPULAN DAN SARAN \\ Simpulan}

Kegiatan pengabdian kepada masyarakat di TK. Serathi Dharma Dusun Tampak Siring, Kecamatan Timoho timur, Kabupaten Luwu Timur Provinsi Sulawesi Selatan. Terjadi peningkatan pemahaman tentang keterampilan mengajar guru sangat signifikan hal ini telah dibuktikan berdasarkan angket yang disebarkan oleh tim saat observasi dan setelah memberikan pelatihan. Berdasarkan data penilaian dibagi menjadi tiga katagori dan semua katagori mengalami peningkatan. sehingga guru perlu persiapan yang matang diawal. sebelum melaksanakan proses belajar mengajar dengan menyusun RPPH sesuai dengan gaya mengajar guru PAUD serta RPPH bukan pelengkap administrasi ketika ada akreditasi.

Setelah menyusun RPPH dapat dipelajari dan dipahami materi atau tema yang akan dipraktekan kepada peserta didik supaya terjadi pengembangan materi guna memudahkan peserta didik untuk memahami apa yang disampaikan oleh guru. Dengan diberikan pelatihan dan pengembangan keterampilan guru PAUD TK. Serathi Dharma menjadi lebih memahami pentingnya diterapkan langkah demi langkah yang telah direncanakan agar proses pembelajaran dikelas berlangsung secara sistematis dan tepat sasaran.

\section{Saran}

Diharapkan adanya pelatihan pelatihan lanjutan untuk meningkatkan kemampuan para guru khususnya keterampilan proses belajar mengajar. Serta terjadinya permasalahan di 
TK. Serathi Dharma perlu didorong dengan liniernya jurusan yang ditempuh oleh guru.

\section{UCAPAN TERIMAKASIH}

Tim mengucapkan terima kasih kepada STAHN Gde Pudja Mataram melalui LP3M atas bantuan dana pengabdian tahun 2019, dan juga pimpinan Fakultas Dharma Acarya yang mendukung kegiatan pengabdian ini.

\section{DAFTAR RUJUKAN}

Abril, D. W. (. (2016). Permendikbud No.22 Tahun 2016. Revista Brasileira de Ergonomia, 9(2).

Ardika Yasa, I. M. (2020). Nilai-Nilai Pendidikan Dalam Budaya Tarung Presean Di Lombok Barat (Perspektif Agama Hindu). Jurnal Penelitian Agama Hindu, 4(1). https://doi.org/10.25078/jpah.v4i1.1334

Felayati Felayati, \& Nurhafizah Nurhafizah. (2019). Ugensi Assesment Guru Pauprofesional Berbasis Kompetensi Personality. Jurnal Pendidikan Tambusai, $3(2)$.

Gunada, I. W. A., \& Yoga Pramana, I. B. K. (2021). Desain Pelatihan Menggambar Ornamen Bali Sebagai Implementasi Nilai Pendidikan Agama Hindu. Jurdimas (Jurnal Pengabdian Kepada Masyarakat) Royal, $4(1)$. https://doi.org/10.33330/jurdimas.v4i1.90 9

Kasiyan, K., Zuhdi, B. M., Hendri, Z., Handoko, A., \& Sitompul, M. (2019). Pelatihan Penulisan Karya IImiah Untuk Peningkatan Profesionalisme Guru. JPPM (Jurnal Pengabdian Dan Pemberdayaan Masyarakat), $3(1)$. https://doi.org/10.30595/jppm.v3i1.3128

Kemendikbud. (2013). Kurikulum 2013. In Http://Kemdikbud.Go.ld/(Issue Mei).

Lestari, P. W., \& Millenia, S. J. (2020). Peningkatan pemahaman anak melalui edukasi dampak penggunaan gawai berlebih 1,2. JMM (Jutnal Masyarakat Mandiri), 4(2).

Mayudana, I. K. Y., \& Sukendra, I. K. (2020). Analisis Kebijakan Penyederhanaan Rpp (Surat Edaran Menteri Pendidikan Dan Kebudayaan Nomor 14 Tahun 2019). IJED (Indonesian Journal of Educational Development), 1(1).

Murdri, M. W. (2010). Kompetensi dan Peranan Guru dalam Pembelajaran. Falasifa, 1 No.1.

Nurhafizah, N. (2018). PELATIHAN PEMBUATAN MEDIA PEMBELAJARAN ANAK USIA DINI MENGGUNAKAN BAHAN SISA. EARLY CHILDHOOD: JURNAL PENDIDIKAN, 2(2b). https://doi.org/10.35568/earlychildhood.v 2i2b.288

Putra, F. F., Sari, J. N., \& Suhatman, R. (2012). Aplikasi Pembelajaran Metamorfosis Berbasis Android Augmented Reality. Jurnal Aksara Komputer Terapan, 1 (September).

Republik Indonesia. (2005). Undang-Undang Nomor 14 Tahun 2005 tentang Guru dan Dosen. Sekretariat Negara.

Rudiarta, I. W. (2020). Implikasi Latihan Yoga Asana Bagi Pembentukan Karakter Siswa Di Ashram Gandhi Puri Sevagram Klungkung. Jurnal Penelitian Agama Hindu, $4(1)$. https://doi.org/10.25078/jpah.v4i1.1314

Sutarmanto, S. (2012). KOMPETENSI DAN PROFESIONALISME GURU PENDIDIKAN ANAK USIA DINI. Jurnal Visi IImu Pendidikan, 1(1). https://doi.org/10.26418/jvip.v1i1.42

Wiguna, I. B. A. A. (2020). Student responses on the application of Hypnoteaching method to increase learning activities. Jurnal Pendidikan Dan Pengajaran, 53(2). https://doi.org/10.23887/jpp.v53i2.23346

Yuliariatiningsih, M. S., \& Setiaty, T. (2018). KOMPETENSI PEDAGOGIK GURU PAUD DALAM MENGEMBANGKAN PEMBELAJARAN UNTUK ANAK USIA DINI. Cakrawala Dini: Jurnal Pendidikan Anak Usia Dini, 3(1). https://doi.org/10.17509/cd.v3i1.10325 